IZA DP No. 10053

The Gender Gap in Mathematics Achievement: Evidence from Italian Data

Maria Laura Di Tommaso

Silvia Mendolia

Dalit Contini

July 2016 


\title{
The Gender Gap in Mathematics Achievement: Evidence from Italian Data
}

\author{
Maria Laura Di Tommaso \\ University of Turin and Collegio Carlo Alberto
}

Silvia Mendolia

University of Wollongong and IZA

Dalit Contini

University of Turin

\section{Discussion Paper No. 10053 \\ July 2016}

IZA

\author{
P.O. Box 7240 \\ 53072 Bonn \\ Germany
}

Phone: +49-228-3894-0
Fax: +49-228-3894-180
E-mail: iza@iza.org

Any opinions expressed here are those of the author(s) and not those of IZA. Research published in this series may include views on policy, but the institute itself takes no institutional policy positions. The IZA research network is committed to the IZA Guiding Principles of Research Integrity.

The Institute for the Study of Labor (IZA) in Bonn is a local and virtual international research center and a place of communication between science, politics and business. IZA is an independent nonprofit organization supported by Deutsche Post Foundation. The center is associated with the University of Bonn and offers a stimulating research environment through its international network, workshops and conferences, data service, project support, research visits and doctoral program. IZA engages in (i) original and internationally competitive research in all fields of labor economics, (ii) development of policy concepts, and (iii) dissemination of research results and concepts to the interested public.

IZA Discussion Papers often represent preliminary work and are circulated to encourage discussion. Citation of such a paper should account for its provisional character. A revised version may be available directly from the author. 


\title{
ABSTRACT \\ The Gender Gap in Mathematics Achievement: Evidence from Italian Data
}

\begin{abstract}
Gender differences in the STEM (Science Technology Engineering and Mathematics) disciplines are widespread in most OECD countries and mathematics is the only subject where typically girls tend to underperform with respect to boys. This paper describes the gender gap in math test scores in Italy, which is one of the countries displaying the largest differential between boys and girls according to the Programme for International Student Assessment (PISA), we use data from an Italian national level learning assessment, involving children in selected grades from second to tenth. We first analyse the magnitude of the gender gap using OLS regression and school fixed-effect models for each grade separately. Our results show that girls systematically underperform boys, even after controlling for an array of individual and family background characteristics, and that the average gap increases with children's age. We then study the gender gap throughout the test scores distribution, using quantile regression and metric-free methods, and find that the differential is small at the lowest percentiles of the grade distribution, but large among top performing children. Finally, we estimate dynamic models relating math performance at two consecutive assessments. Lacking longitudinal data, we use a pseudo panel technique and find that girls' average test scores are consistently lower than those of boys at all school years, even conditional on previous scores.
\end{abstract}

JEL Classification: J16, I24, C31

Keywords: math gender gap, education, school achievement, inequalities, cross-sectional data, pseudo panel estimation, quantile regression

Corresponding author:

Silvia Mendolia

School of Accounting, Economics and Finance

University of Wollongong

Northfields Avenue

North Wollongong, NSW 2522

Australia

E-mail: smendoli@uow.edu.au 


\section{Introduction}

The traditional gender gap in educational outcomes advantaging boys has been completely filled up in most industrialized countries, and has now reversed in favour of girls. Girls tend to do better than boys in reading test scores, in grades at school, in the propensity to choose academic educational programs in upper secondary school, in tertiary education attendance and graduation rates. In this perspective, there is now an extensive literature addressing the underperformance of boys (Department for Education and Skills 2007; Legewie and DiPrete 2012). However, boys keep doing better than girls in math tests. According to The Programme for International Student Assessment (PISA), the average gender differential within OECD countries in mathematics at age 15 is 0.11 standard deviations in favour of males (OECD 2015). Italy is one of the countries with the largest gap, equal to 0.24 standard deviations. The presence of a substantial females' disadvantage in math is of particular importance, because it is likely to be a cause of the critically low share of women choosing STEM (Science Technology Engineering and Mathematics) disciplines at university, of gender segregation in the labour market, and gender pay gaps (European Commission 2006, 2012, 2015; National Academy of Science, 2007).

Several explanations have been proposed for the existence of the gender gap in mathematics. Some scholars refer to biological factors (Baron-Cohen and Wheelwright 2004, Baron Cohen et al 2001). However, as shown by international assessments (OECD 2015, Mullis et al, 2012) the gender gap in math differs substantially across countries. Hence, "nature" cannot be the only account for the females' disadvantage in math; there must be alternative explanations related to societal and cultural factors, supporting the existence of "nurture" effects. In this perspective, some scholars (Guiso et al., 2008, De San Roman and De La Rica Goiricelaya, 2012; OECD 2015) provide evidence that the gender gap in math in the PISA survey is negatively related to country level indexes of gender equality.

Focusing on micro-level mechanisms, the literature emphasizes the importance of parents and teachers' beliefs about boys and girls capacities. Gender-stereotypes in parent's evaluation of children abilities have been found to affect achievements and children's self-perception (amongst others: Jacobs 1991; Jacobs and Bleeker 2004; Jacobs and Eccles 1992; Bhanot and Jovanovic 2009; Twenge and Campbell 2001). Fryer and Levitt (2010) show that parental expectations regarding performance in math are lower for girls than for boys even after accounting for test scores. However, Cornwell et al (2012) and Robinson et al (2014) find that teachers rated girls' math skills higher than those of observationally similar boys. 
Although the causal direction is difficult to assess, girls display less math self-efficacy (selfconfidence in solving math related problems) and math self-concept (beliefs in their own abilities), and more anxiety and stress in doing math related activities (OECD 2015, Heckman and Kautz 2012, 2014; Lubienski et al 2013, Twenge and Campbell 2001). As demonstrated by the recent work by Heckman and colleagues (e.g. Heckman and Kautz 2012, 2014; Heckman and Mosso, 2014), non-cognitive abilities including motivation and self-esteem are important predictors of success in life and in the labour market. In this perspective, the females' lower self-esteem in math could be responsible of their relatively poorer performance in STEM subjects and future educational choices and occupational outcomes.

Socioeconomic status, parental education and occupation play a major role on school achievement, including math performance. In particular, parenting styles and parents' nvolvement in children's homework are relevant (Bhanot and Jovanovic 2009, Del Boca, et al 2014, Brilli et al. 2016). Home experiences differ in stereotypical gendered ways, and according to Lubienski et al. (2013), somewhat unexpectedly, more strongly among children of high socioeconomic status. Whether these factors also contribute to determining the gender gap in math test scores is still unclear. However, there is empirical evidence that girls with mothers working in math-related occupations lag behind boys as much as those whose mothers are not in math-related occupations (Fryer and Levitt, 2010; OECD 2015)

Schools and educational methods and practices also seem to matter. The educational literature provides evidence that different approaches to math and physics can decrease gender inequality in achievements. Problem solving, class-discussions and investigative work and cognitive activation strategies have been found to improve girls' performances (Boaler 2002; Zohar and Sela 2003; OECD 2015). In addition, Boaler et al. (2011) and Good, Woodzicka, and Wingfield (2010) analyse other factors affecting lower achievement in math and science related to gender-stereotypes, such as images shown in textbooks, and show that girls' proficiency increases by using counter-stereotypic pictures with female scientists.

From a policy perspective, it is important to describe when the gap first shows up. Does it already exist at the beginning of primary school? The existing evidence is mainly based on the US dataset "Early Childhood Longitudinal Study, Kindergarten Class of 1998- 1999” (ECLS-K) following students from kindergarten through eighth grade. The main finding from these data is that the math gender gap starts as early as in kindergarten and increases with the age of the child (Robinson and Lubiensky, 2011; Fryer and Levitt, 2010; Penner and Paret, 2008). Another relevant result is that 
the math gender gap is higher for top performing students. Initially boys appear to do better than girls among well performers and worse at the bottom of the distribution; by third grade, the gender gap, still larger at the top, appears throughout the distribution. Moreover, the male advantage among high performers is largest among families with high parental education. Girls appear to lose ground in math over time in every family structure, ethnic group, and level of the socio-economic distribution (Fryer and Levitt, 2010). These findings are confirmed by PISA international data, on children of age 15 (OECD, 2015).

Differently from the US, there seems to be little concern on the math gender gap in Europe. Longitudinal studies in UK (LSYPE and the Millennium Cohort Study) report limited evidence of a substantial gender gap in math (Department for Education and Skills 2007), and the NEPS study in Germany does not focus on gender inequalities (Blossfeld et al. 2011). However, according to the PISA assessment (OECD, 2012), both countries display a significant math gender gap in favour of boys at age 15. As for Italy, there are currently no systematic contributions on achievement gender differentials over childhood.

This paper contributes to the existing literature in a number of ways. Firstly, it provides detailed evidence on the gender gap in math test scores in Italy, one of the countries with the largest differential favouring boys over girls at age 15 (OECD 2015). We exploit the cross-sectional data of the National Assessment carried out by INVALSI $^{1}$ in 2013, testing the entire population of Italian children in school years 2, 5, 6, 8 and 10. In particular, we analyse the gender gap at different school years to identify when the gap first emerges, and to study its evolution throughout compulsory schooling. Secondly, by focusing on differentials along the entire test score distribution, we apply quantile regression and metric free methods to analyse where the girls' disadvantage is more severe. Lastly, we estimate dynamic models relating math performance at two consecutive assessments. Unfortunately, there isn't any suitable longitudinal dataset on Italian students and therefore we use imputed regression to identify "new" gender effect operating between the two surveys and disentangling it from carryover effects of previously established inequalities. We find that the performance of girls is always lower than the one of boys, even given conditioning on previous test scores. Altogether, this body of evidence confirms that the qualitative findings on gender inequalities in math test scores observed in US data also apply to Italy.

\footnotetext{
${ }^{1}$ INVALSI stands for "Istituto nazionale per la valutazione del sistema educativo di istruzione e di formazione" (National Institute for the evaluation of education and training).
} 


\section{Modelling strategies}

\section{$\underline{\text { Cross-sectional models }}$}

Since test scores are not measured on the same scale at different school years, the gender gap on original scores is not comparable across grades. For this reason, we use standardized scores and the gender gap results show by how many standard deviations girls and boys differ.

First, we focus on the total effect of gender on average math achievement. We estimate an OLS model with standardized test scores as dependent variables, gender as the independent variable of interest, and a set of control variables describing maternal and parental education, socio-economic status of the family, geographical area and number of siblings.

Second, if school characteristics influence children' learning, the effect of gender might operate both indirectly via school choices and directly net of school characteristics. The existence of an indirect effect could play a role in particular after tracking into different educational programs has taken place (see section 3), but it might also apply at earlier stages of schooling. Students attending the same school are exposed to a similar environment in the student body composition (in terms of gender, socioeconomic status, and immigrant background), learning targets, educational practices, and gender stereotypes, that might affect the performance of girls and boys differently. For these reasons, we estimate the direct effect of gender on math achievement estimating a model including school fixed effects, which exploit within-school variability, and deliver valid estimates of the gender gap given individual controls and (observed and unobserved) school characteristics.

Third, we shift the focus from the expected value of test scores to the entire test score distributions of girls and boys and analyse gender differentials at different points of the ability distribution. To this aim, we estimate quantile regression models (Koenker and Basset, 1978). In essence, with these models we inspect the gender gap at different percentiles of the grade distribution, and assess whether female's disadvantage in math exists throughout the distribution, or instead is stronger among low performing or top performing children. In the simplest case where gender is the only explanatory variables, the quantile regression coefficient gives the difference between the score corresponding to a specific percentile of the girls' distribution and the score corresponding to the same percentile of the boys' distribution.

A limitation of the methods described so far is that test scores are considered on the interval scale, implicitly relying on stringent psychometric assumptions, and in particular that there is the same difference in cognitive ability between two children scoring $70 \%$ and $80 \%$ and between two 
children scoring $40 \%$ and $50 \%$. An alternative approach is given by metric-free methods that rely instead on the relative position that girls and boys occupy in the overall ranking. Following Robinson and Lubienski (2011), we analyze the gender gap throughout the distribution by estimating at specific percentiles $\theta$ the following:

$$
\lambda_{\theta}= \begin{cases}\frac{\varphi_{M}(\theta)}{\varphi_{M}(\theta)+\varphi_{F}(\theta)} & \text { if } \theta<50 \\ \frac{1-\varphi_{F}(\theta)}{2-\left(\varphi_{M}(\theta)+\varphi_{F}(\theta)\right)} & \text { if } \theta \geq 50\end{cases}
$$

where $\varphi_{M}($.$) and \varphi_{F}($.$) are the cumulative distribution functions of males and females at the \theta$ th percentile of the overall distribution. Values of $\lambda_{\theta}$ below 0.5 indicate a girls' disadvantage. For example, $\varphi_{F}(20)$ is the percentage of females below or at the $20^{\text {th }}$ percentile of the overall distribution. If $\varphi_{F}(20)>\varphi_{M}(20)$, more girls perform below the $20^{\text {th }}$ percentile than boys and thus $\lambda_{\theta}<0.50$. Instead, $1-\varphi_{F}(80)$ is the percentage of females above or at the $80^{\text {th }}$ percentile of the overall distribution. So, if $1-\varphi_{F}(80)<1-\varphi_{M}(80)$, a lower share of girls perform above the $80^{\text {th }}$ percentile as compared to the share of boys, and, again, $\lambda_{\theta}<0.50$.

\section{$\underline{\text { Dynamic models }}$}

Cross-sectional analyses do not allow exploring the mechanisms underlying the development of inequalities as children grow. Cross-sectional regression coefficients at age $t$ represent the effects accumulated up to age $t$ and do not allow distinguishing between new effects operating between two successive assessments and carryover effects of pre-existing achievement gaps between girls and boys. Further, coefficients based on standardized test scores also depend on the achievement variability at each assessment. ${ }^{2}$ Hence, if this variability increases between two surveys for reasons not related to gender (for example, due to increasing differences across socioeconomic levels), we might observe a diminishing gender gap even if there are no forces at work making girls catching up the previous disadvantage (Contini and Grand, 2016).

In this perspective, we aim at estimating a simple dynamic model, relating achievement at a given time point $(t=2)$ to previous achievement (at $t=1)$ and individual characteristics, including gender. In the absence of longitudinal data, we use pseudo-panel techniques proposed by De Simone (2013) and Contini and Grand (2016), allowing to estimate simple dynamic models with repeated cross-

\footnotetext{
${ }^{2}$ Ignoring other control variables, the standardized gender gap at age/year $j$ is: $\left(\bar{Y}_{J, B}-\bar{Y}_{J, G}\right) / \sigma_{Y j}$. Clearly, the score variability $\sigma_{Y j}$ may vary over time as a result of multiple driving forces, including increasing differences across social backgrounds or ethnic status.
} 
sectional data. The basic idea is that the unobserved lagged dependent variable can be replaced by a predicted value from an auxiliary regression using individuals observed in previous cross-sections. This strategy delivers consistent estimates under quite restrictive conditions - for example, if there are no time-varying exogenous variables or the time-varying exogenous variables are not autocorrelated (Verbeek and Vella, 2005). These conditions apply to our case study, because the explanatory variable of main interest is gender and the other control variables are time-invariant sociodemographic variables. ${ }^{3}$

In this paper, we apply the method adopted in Contini and Grand (2016). To illustrate its rationale, consider two cross sectional assessments using a single scale to measure achievement (i.e. "vertically equated" scores). Subsequent scores follow the relation:

$y_{i 2}=y_{i 1}+\delta_{i}$

where $\delta_{i}$ is achievement growth, that may vary across individuals and depend linearly on individual characteristics $x_{i}$ and previous achievement:

$\delta_{i}=\Delta+\beta x_{i}+\theta y_{i 1}+\varepsilon_{i 2}$.

Under these assumptions, the dynamic model relating achievement at the two occasions is:

$$
y_{i 2}=\Delta+(1+\theta) y_{i 1}+\beta x_{i}+\varepsilon_{i 2} \text {. }
$$

The parameter of interest is $\beta$, representing the difference between test scores at $t=2$ of a boy and a girl with identical performance at $t=1$. Hence, $\beta$ captures gender inequalities developed between the two surveys. Instead, $\theta$ are carry-over effects of inequalities already existing at $t=1$.

When achievement scores are not equated, the relation between subsequent scores is:

$$
y_{i 2}=\tilde{y}_{i 1}+\delta_{i}
$$

where $\tilde{y}_{i 1}$ represents achievement at $t=1$ in the measurement scale employed at $t=2$. Assuming that $\tilde{y}_{i 1}=\varphi+\omega y_{i 1}$ (where $\varphi$ and $\omega$ are not known and not identifiable), the dynamic model becomes:

$y_{i 2}=\varphi(1+\theta)+\Delta+\omega(1+\theta) y_{i 1}+\beta x_{i}+\varepsilon_{i 2}$

If test scores are measured on different scales, $\theta$ is always unidentified. Instead, $\beta$ is identified and can be estimated even with repeated cross-sectional data.

\footnotetext{
${ }^{3}$ Note that the inclusion of school characteristics in the model would invalidate the estimation, because school features are typically correlated to the error term (that incorporates innate ability), because higher ability children usually choose schools with more favorable characteristics (Contini and Grand, 2016). Similar conclusion would apply if we were to include other endogenous variables capturing behavior and attitudes.
} 
We begin by estimating the cross sectional model for test scores at $t=1$ :

$$
y_{i 1}=\mu_{1}+\rho x_{i}+\delta w_{i}+\varepsilon_{1 i}
$$

where $w$ is an appropriate instrumental variable affecting achievement at $t=1$ but not affecting achievement at $t=2$ given achievement at $t=1$. Following Contini and Grand (2016), we use the month of birth, since there is widespread evidence - confirmed by our data - that younger children generally underperform their older peers, in particular at early school stages. Further, the identifying assumption is that achievement at a given school year is not affected by the age of the child, given earlier achievement. ${ }^{4}$

In the second step, we substitute $y_{1}$ with its OLS estimate $\hat{y}_{1}$ and plug it in model (6). This introduces measurement error $\hat{y}_{1}-y_{1}$ in previous scores; however, due to properties of OLS estimates, this measurement error (which enters the error term) will be uncorrelated to $x$ and $\hat{y}_{1}$. The final model is:

$y_{i 2}=\mu_{2}+\gamma \hat{y}_{1 i}+\beta x_{i}+u_{2 i}$

Model (8) will deliver consistent estimates of $\beta$.

The major drawback of this approach is that the standard errors will be largely inflated, and therefore the sample size is critical in order to obtain reliable estimation coefficients.

\footnotetext{
${ }^{4}$ The use of the season of birth as an instrumental variable to account for the endogeneity of children's age on later outcomes has recently been questioned by Buckles and Hungerman (2013). They argue that, contrary to common belief, the season of birth is not totally idiosyncratic; in fact in USA winter births are disproportionally represented by teenagers and unmarried mothers. However, in this paper we use the month of birth (and not the season) to measure the age of the child, as our assumption is that the age of the child affects earlier achievement, but does not affect later achievement given earlier achievement. If this assumption is credible, we can estimate the effects of sociodemographic variables net of previous achievement consistently
} 


\section{Italian education system and data}

The Italian education system is organised in three stages. Students attend primary school from the age of 6 until the age of 11 years old. At the end of primary school, they enrol in middle school, and remain within the same institution (and in the same class) from the age of 11 until the age of 14 years old. High school begins at the age of 14 and lasts for five years, but compulsory education terminates at 16 years old, so a relevant share of children does not attain the upper secondary school qualifications.

At the end of middle school, students choose among different kinds of high schools, with significant differences in the curriculum. These educational programs are broadly classified into three main types: the Lyceum, the Technical High School and the Vocational High School. The curriculum is generally organised at national level and all high schools have to offer some compulsory subjects (Italian, Mathematics, Sciences, History, one or two foreign languages and Physical Education). However, there are significant differences in terms of the time allocated to each subject, and the specialised field of studies. Lyceums generally provide higher-level academic education, with a specialisation in the humanities, sciences, languages or arts. Technical institutes usually provide students with both a general education and a qualified technical specialization in a particular field (e.g.: business, accountancy, tourism, technology). Vocational institutes have specified structures for technical activities, with the objective of preparing students to enter the workforce.

This study uses data from the National Test INVALSI for 2013, assessing the reading and mathematical skills of Italian pupils. Since 2009, all Italian children have been tested by the INVALSI during school years 2, 5, 6, 8 and 10. More than half a million students in each grade sit this test each year.

INVALSI assesses the overall population of students enrolled in Italian schools but a subsample of schools and students takes the tests under the supervision of an external inspector. To ensure better data quality in our analysis, we only use the subsample of children whose test was supervised by an external inspector.

We also restrict the sample to native children, mostly because recent migrants may be enrolled in classes that are not necessarily aligned with their age, depending on their level of fluency in Italian. Further, immigrants experience grade repetition more frequently than native students. Our final sample includes around 23,000 observations from year 2; 22,000 from year 5; 24,000 from year 6 (first year of middle school); 25,111 from year 8 (third year of middle school) and 34,000 from year 10 (second year of high school). 
In addition to test scores, INVALSI data includes information on parental characteristics and family background, collected from a questionnaire submitted to the students and from school board records. Among the variables on family background, for years 5, 6, and 10, INVALSI provides a synthetic indicator of economic and socio-cultural status (ESCS) similar to that the one available in PISA, by taking into consideration parental educational background, their employment and occupation, and home possessions. Moreover, children in years 5, 6 and 10 are asked questions regarding their beliefs on their own abilities in the subjects of the test, and on the importance of language and math for their future studies, life, and career. Full descriptive statistics for the variables used in the estimation are provided in tables A1 and A2.

\section{Results}

\section{$\underline{\text { Average gender gap }}$}

Table 1 shows average test scores in mathematics for girls and boys, by school year and gender. Since tests at different age are not equated (i.e. measured on the same scale), comparing the difference of raw scores across school years is not meaningful, so we use the standardized achievements. For example, a value of -0.02 indicates that this value is 0.02 standard deviations below the mean. The gender gap in math already exists at grade 2, and increases throughout the grade distribution

Table 1 - Average test scores in Maths and the gender gap

\begin{tabular}{lccccc}
\hline Standardised scores & Year 2 & Year 5 & Year 6 & Year 8 & Year 10 \\
& & & & & \\
\hline \multirow{2}{*}{ Boys } & 0.019 & 0.079 & 0.075 & 0.090 & 0.14 \\
& $(1.007)$ & $(0.99)$ & $(1.03)$ & $(1.00)$ & $(1.04)$ \\
Girls & -0.021 & -0.060 & -0.076 & -0.090 & -0.13 \\
& $(0.991)$ & $(0.99)$ & $(0.95)$ & $(0.98)$ & $(0.93)$ \\
\hline
\end{tabular}

Note: Standard deviation in brackets.

Table 2 shows the impact of the gender variable when the estimation is performed using OLS and school fixed effect regression models with region of residence, maternal and paternal education, ESCS and number of siblings as controls. 
Table 2 - The gender gap (G-B) in math test scores. OLS and school fixed effects.

\begin{tabular}{lccccc} 
& Year 2 & Year 5 & Year 6 & Year 8 & Year 10 \\
\hline OLS & -0.105 & -0.186 & -0.183 & -0.184 & -0.306 \\
& $(0.014)^{* * *}$ & $(0.013)^{* * *}$ & $(0.012)^{* * *}$ & $(0.012)^{* * *}$ & $(0.010)^{* * *}$ \\
Fixed Effects & -0.099 & -0.193 & -0.178 & -0.191 & -0.279 \\
& $(0.012)^{* * *}$ & $(0.012)^{* * *}$ & $(0.012)^{* * *}$ & $(0.011)^{* * *}$ & $(0.009)^{* * *}$ \\
$\mathrm{~N}$ & 21988 & 21207 & 24074 & 25111 & 33479 \\
\hline
\end{tabular}

Notes. Std errors are in brackets. * indicates that the underlying coefficient is significant at $10 \%$ level, $* *$ at $5 \%$ and $* * * 1 \%$. All models include region of residence, maternal and paternal education, ESCS (not available in years 2 and 8 ) and number of siblings (not available in years 2 and 8). They also include an interaction effect between gender and ESCS. The results reported in this table refer to the gap at ESCS=0 (approximately the mean value of ESCS).

Gender has a significant and sizable effect on test scores in mathematics at all ages. According to these estimates, the gap increases markedly between year 2 and 5, remains stable up to year 8 and increases again between year 8 and 10. There are little changes also when adopting a school-fixed effect model, implying that there is no substantial indirect effect of gender via school characteristics, not even at year 10, where schools differ markedly and the choice between school types is strongly related to individual and family characteristics.

The complete set of results on the effects of all control variables are reported in the Appendix (Table A2). As expected, parental education and socio-economic status are strong determinants of students' achievement. Consistently with the literature, we find that girls benefit less from family resources than boys, as shown by the negative sign (although not always significant) of the interaction term between gender and ESCS. In other words, the gap between girls and boys is larger among children of high social background. This effect emerges more clearly in high school. In addition, we observe dramatic differences in test scores across geographical areas and sizable differences related to the number of siblings. Interestingly, while the gender gap changes little with school-fixed effect estimation, in year 10 within-school differences across social groups (identified by parental education and ESCS) are relatively weak as compared to OLS estimates. Hence, the sorting into different high school types - a highly gendered and socially selective process - has a strong mediating effect on socioeconomic background achievement inequalities, while it does not appear to play a relevant mediating role on the establishment of gender differences in math achievement. 
The gender gap over the entire test score distributions

Table 3 summarizes the gender effect from quantile regression. These findings show that in all school years the gap between girls' and boys' performance in mathematics increases throughout the grade distribution. In year 2, we observe no differences between girls' and boys' performance at the tenth percentile of the grade distribution. The gap between girls and boys at the first quartile of the distribution is about 0.05 standard deviations, and it is more than 0.14 standard deviations at the third quartile. These gaps widen in later grades. By year 10, girls at the first quartile underperform boys by 0.18 standard deviations, whereas the gap between students in the top $10 \%$ of the distribution is more than 0.4 standard deviations. ${ }^{5}$ Our results confirm the finding for the US that the girls disadvantage increases over time and is larger at the top of the distribution (Robinson and Lubiensky 2011; Fryer and Levitt 2010).

\section{Table 3 - Gender gap in achievements in Mathematics - Quantile Regression}

\begin{tabular}{llllll} 
& Year 2 & Year 5 & Year 6 & Year 8 & Year 10 \\
\hline Q10 & 0.000 & -0.132 & -0.073 & -0.117 & -0.131 \\
& $(0.008)$ & $(0.018)^{* * *}$ & $(0.014)^{* * *}$ & $(0.037)^{* * *}$ & $(0.011)^{* * *}$ \\
Q25 & -0.048 & -0.183 & -0.127 & -0.233 & -0.180 \\
& $(0.023)^{* * *}$ & $(0.018)^{* * *}$ & $(0.015)^{* * *}$ & $(0.028)^{* * *}$ & $(0.012)^{* * *}$ \\
Q50 & -0.145 & -0.203 & -0.181 & -0.233 & -0.268 \\
& $(0.038)^{* * *}$ & $(0.027)^{* * *}$ & $(0.013)^{* * *}$ & $(0.034)^{* * *}$ & $(0.013)^{* * *}$ \\
Q75 & -0.145 & -0.244 & -0.256 & -0.233 & -0.341 \\
& $(0.021)^{* * *}$ & $(0.023)^{* * *}$ & $(0.021)^{* * *}$ & $(0.032)^{* * *}$ & $(0.015)^{* * *}$ \\
Q90 & -0.145 & -0.201 & -0.282 & -0.233 & -0.423 \\
& $(0.026)^{* * *}$ & $(0.024)^{* * *}$ & $(0.026)^{* * *}$ & $(0.031)^{* * *}$ & $(0.025)^{* * *}$ \\
\hline
\end{tabular}

Notes: Std errors are in brackets. * indicates that the underlying coefficient is significant at $10 \%$ level, $* *$ at $5 \%$ and $* * * 1 \%$. All models include region of residence, maternal and paternal education, ESCS (not available in years 2 and 8 data) and number of siblings (not available in years 2 and 8).

In order to check the robustness of our estimates in the quantile regression, we compute the metricfree gap at different points in the achievement distribution (see Section 2). Metric-free findings qualitatively confirm the results obtained with quantile regression. Figure 1 presents metric-free measures of the math gap throughout the test scores distribution in year 2, 5, 6, 8 and 10. Values of $\lambda$ below 0.5 indicate a boys' advantage, while above 0.5 indicate a girl's advantage. Figure 1 shows that the gap significantly favours males at all percentiles. For instance, in year $2, \lambda 95$ is equal to 0.4 , which means that if girls and boys where equal in number, the top $5 \%$ of the distribution would be composed by $40 \%$ of girls and $60 \%$ of boys. On the other hand, the proportion of boys and girls is nearly even ( $\lambda$ almost equal to 0.5$)$ at the $10^{\text {th }}$ percentile of the distribution. Consistently with the

\footnotetext{
${ }^{5}$ OECD 2015 reports similar results for Italian children in PISA data at age 15.
} 
quantile regression findings, the largest gender gap is observed in year 10 at the top $10 \%$ of the grade distribution, where the adjusted proportion of females is as low as $33 \%$.

Figure 1 - Metric-free gender gap in achievements in Maths throughout the distribution

Lambda Year 2

Lambda Year 5

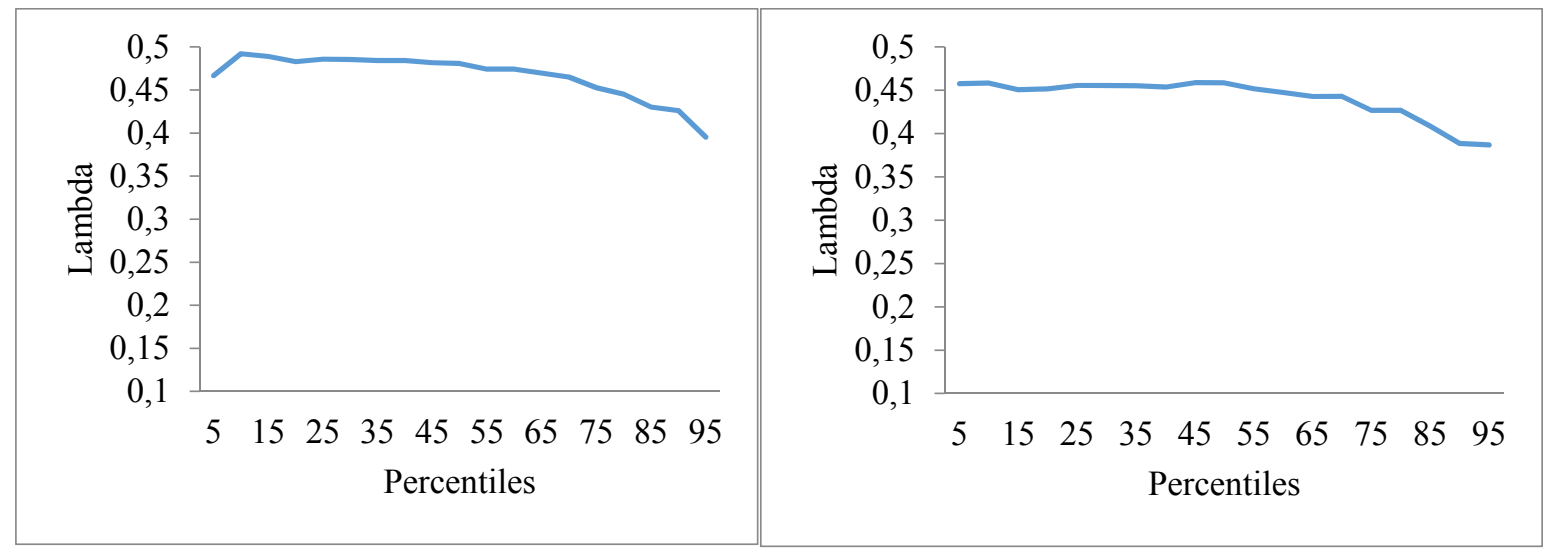

Lambda Year 6

Lambda Year 8

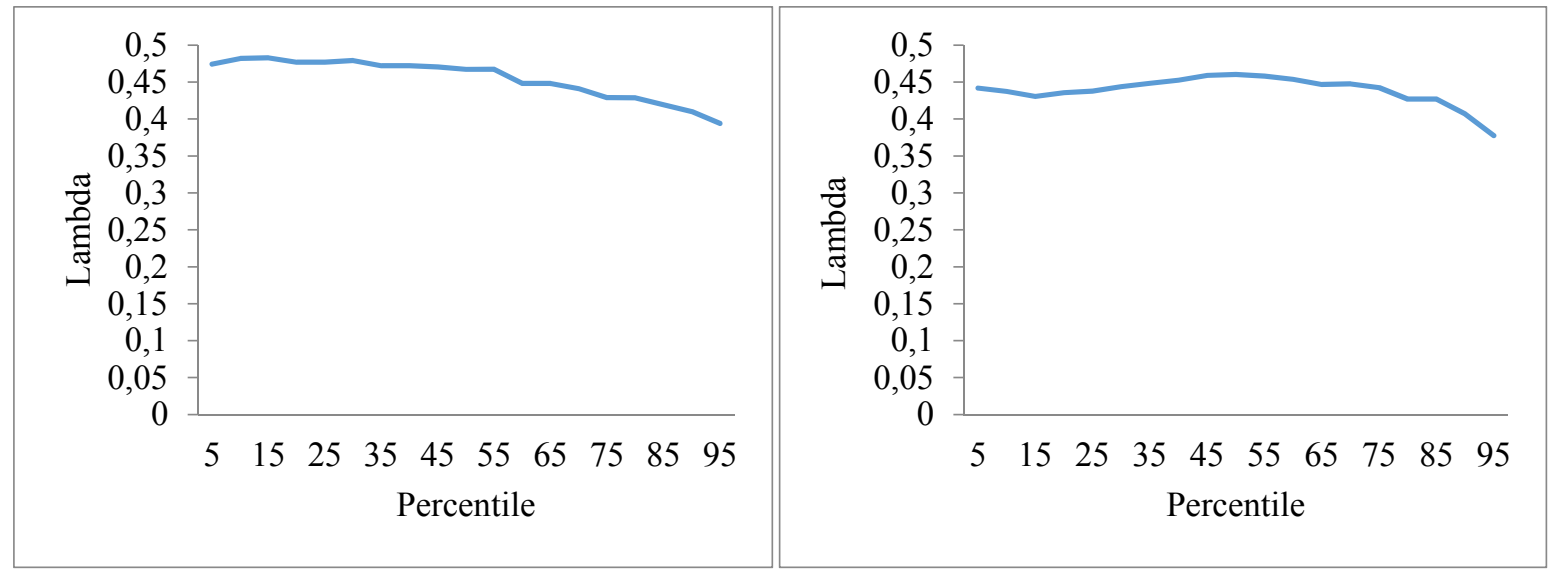

\section{Lambda Year 10}

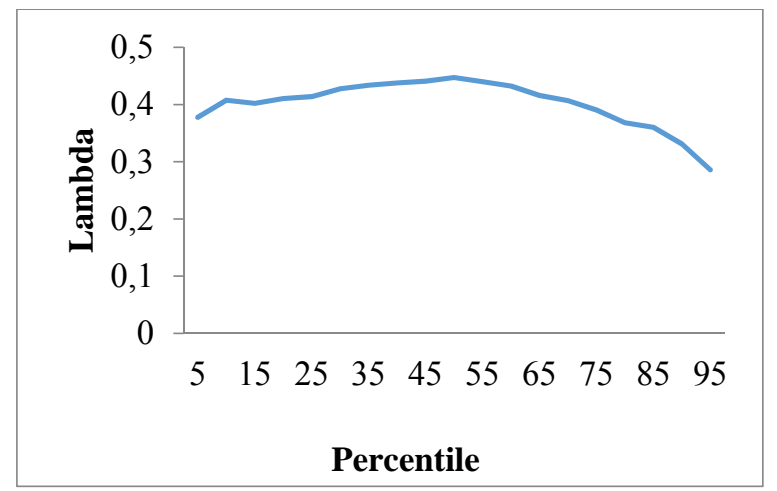

Note: $\lambda$ equal to 0.5 means that boys' and girls' grades are aligned. $\lambda$ values closer to 0 benefit boys while values closer to 1 favour girls. 


\section{Dynamic model estimation}

Table 4 summarizes the results for the gender variable from the pseudo-panel methodology 6 . Columns labelled "CS" include the estimates of the gender coefficient from cross-sectional models, while columns labelled "Dyn" report the corresponding coefficients for dynamic models. In the latter, the coefficients represent the extent to which achievement growth between two consecutive assessments differs across gender, when comparing two equally performing children at the first assessment. We estimate dynamic models relating: year 5 to year 2, year 6 to year 5 , year 8 to year 6, year 10 to year 8. Further, since, as expected, the predictive power of our instrument (the month of birth) decreases substantially as children grow older, becoming very low at year 8, we also estimate a dynamic model relating year 10 to year 6 .

Results show that when comparing girls and boys with the same background characteristics and prior scores, at the following assessment on average boys will always score better than girls. For instance, according to our estimates, if we consider a girl and a boy with the same performance at grade 2 , the expected test score at grade 5 for the girl will be 0.122 standard deviations lower than that of the boy. The progressive deterioration of female's performance relative to males is observed between all pairs of assessments, including between year 5 and 6, despite at the cross sectional level we observed a substantial stability of the standardized gender gap. Our point estimate is -0.051 , meaning that between years 5 and 6 girls lose on average 0.051 standard deviations relative to boys. These cross-sectional and dynamic results are not inconsistent, because as argued in section 2, if other inequalities operate (for example, between social backgrounds) we may observe a stable or even decreasing standardized gender gap even if girls and boys are moving further apart. In sum, dynamic modelling shows that the distance between girls and boys keeps widening at all stages under observation.

\footnotetext{
${ }^{6}$ Full estimates available from the authors upon request.
} 
Table 4 - Dynamic models estimation (imputed regression)

\begin{tabular}{|c|c|c|c|c|c|c|c|c|c|}
\hline & $\begin{array}{l}\text { Y-2 } \\
\text { CS }\end{array}$ & $\begin{array}{l}\text { Y-5 } \\
\text { CS }\end{array}$ & $\begin{array}{l}\text { Y-6 } \\
\text { CS }\end{array}$ & $\begin{array}{l}\text { Y-8 } \\
\text { CS }\end{array}$ & $\begin{array}{c}Y-10 \\
\text { CS }\end{array}$ & $\begin{array}{c}\text { Y-5 } \\
\text { Dyn } \\
(\operatorname{lag} y 2)\end{array}$ & $\begin{array}{c}\text { Y-6 } \\
\text { Dyn } \\
(\operatorname{lag} y 5)\end{array}$ & $\begin{array}{c}\mathbf{Y - 8} \\
\text { Dyn } \\
(\operatorname{lag} \text { y6) }\end{array}$ & $\begin{array}{c}\mathbf{Y}-10 \\
\text { Dyn } \\
(\operatorname{lag} y 8)\end{array}$ \\
\hline Female & $\begin{array}{c}-0.105 \\
(0.013) \\
* * *\end{array}$ & $\begin{array}{c}-0.183 \\
(0.013) \\
* * *\end{array}$ & $\begin{array}{c}-0.184 \\
(0.013) \\
* * *\end{array}$ & $\begin{array}{c}-0.222 \\
(0.013) \\
* * *\end{array}$ & $\begin{array}{c}-0.350 \\
(0.011) \\
* * *\end{array}$ & $\begin{array}{c}-0.122 \\
(0.015) \\
* * *\end{array}$ & $\begin{array}{c}-0.051 \\
(0.023) \\
* *\end{array}$ & $\begin{array}{c}-0.160 \\
(0.028) \\
* * *\end{array}$ & $\begin{array}{c}-0.253 \\
(0.075) \\
* * *\end{array}$ \\
\hline Month of birth & $\begin{array}{c}-0.032 \\
(0.002) \\
* * *\end{array}$ & $\begin{array}{c}-0.019 \\
(0.002) \\
* * *\end{array}$ & $\begin{array}{c}-0.015 \\
(0.002) \\
* * *\end{array}$ & $\begin{array}{c}-0.005 \\
(0.002) \\
* *\end{array}$ & $\begin{array}{l}-0.002 \\
(0.002)\end{array}$ & & & & \\
\hline PredictedY1_lag & & & & & & $\begin{array}{c}0.582 \\
(0.065) \\
* * *\end{array}$ & $\begin{array}{c}0.746 \\
(0.105) \\
* * *\end{array}$ & $\begin{array}{c}0.337 \\
(0.134) \\
* *\end{array}$ & $\begin{array}{c}0.436 \\
(0.333)\end{array}$ \\
\hline $\mathbf{N}$ & 19990 & 19006 & 21040 & 21149 & 25826 & 19044 & 20992 & 21149 & 25826 \\
\hline
\end{tabular}

Notes.

- $\mathrm{CS}=$ cross-sectional model. Dyn=dynamic model. Lag y\# = lagged value is the predicted scores at year \#.

- Std errors are in brackets. * indicates that the underlying coefficient is significant at $10 \%$ level, $* *$ at $5 \%$ and $* * * 1 \%$.

- All models include macro-area of residence, maternal and paternal education.

- CS for year 5 and 6 and Dyn models relating year 6 to year 5 also include ESCS and number of books at home (these variables are not available in years 2 and 8 , so they are omitted in the corresponding CS and also in the dynamic models: 5-2, 8-6, 10-8).

- Children anticipating enrolment before the regular grade and children enrolled in lower grades are not included.

- Month of birth measured as: January=1, February=2...December=12.

\section{Summary and conclusions}

In this paper, we have conducted a detailed analysis of the gender gap in math test scores in Italy, one of the countries in the OECD displaying the largest differential between boys and girls in the PISA assessment. We have employed the data from an Italian national learning assessment, testing children in selected grades from second to tenth.

First, we have analysed the magnitude of the standardized gender gap using OLS regression and school fixed-effect models for each school year separately. Our results show that girls systematically underperform boys, even after controlling for individual and family background characteristics, and that the average gap increases with children's age.

Second, we have analysed the gap throughout the test scores distribution, using quantile regressions and metric-free methods, finding that the differential is largest among medium-well performing children at all stages of schooling.

Thirdly, we have estimated dynamic models relating the average math performance at two consecutive assessments, allowing to estimate genuine new gender inequalities developed between two consecutive surveys. By conditioning on previous scores, we identify whether equally performing boys and girls at the first survey still display similar performances at the second, of instead, if they have moved apart. Lacking longitudinal data, we have used a pseudo-panel imputed 
regression technique; our findings show that contrary to cross-sectional findings, gender-specific effects in favour of boys operate at all stages of schooling. Overall, our findings qualitatively confirm previous results from the US data, and represent the first systematic account of gender inequalities in math achievement in Italy.

As highlighted in the introduction, gender related stereotypes are likely to play a major role in the differences between girls and boys cognitive outcomes, both in maths and scientific subjects (where girls are disadvantaged) and reading literacy (where boys are disadvantaged). The analysis of the reasons why the gender gap in maths exists and how it can be reduced in beyond the scope of our contribution. Yet, survey responses regarding self-concept in maths (year 5 and 6) and on the importance of math for their future life (year 10) show that boys are substantially more confident on their own abilities than girls are, and that they are more aware of the importance in math for their future (see Table A4 in the Appendix). In addition - whatever the causal path - we observe that when comparing equally performing students, girls tend to be less confident in their own abilities and attribute less importance to math than their male peers. These aspects certainly deserve further attention of the community of scholars and policy makers. 


\section{References}

Baron-Cohen S, Wheelwright S, Skinner R, Martin J, Clubley E. (2001) The autism-spectrum quotient (AQ): evidence from Asperger syndrome/high-functioning autism, males and females, scientists and mathematicians. J Autism Dev Disord.; 31(1):5-17.

Baron-Cohen S, Wheelwright S. (2004) The empathy quotient: an investigation of adults with Asperger syndrome or high functioning autism, and normal sex differences. J Autism Dev Disord; 34(2):16375.

Bhanot, R. T., \& Jovanovic, J. (2009). The links between parent behaviors and boys' and girls' science achievement beliefs. Applied Developmental Science, 13 (1), $42-59$.

Boaler, J. (2002). Paying the price for 'sugar and spice': shifting the analytical lens in equity research. Mathematical Thinking and Learning, 4(2\&3), 127-144.

Boaler, J, Altendorff, L. \& Kent, G. (2011). Mathematics and science inequalities in the United Kingdom: when elitism, sexism and culture collide. Oxford Review of Education, 37(4), 457-484.

Blossfeld, H.-P., von Maurice, J. \& Schneider, T. (2011). The National Educational Panel Study: need, main features, and research potential. In H.-P. Blossfeld, H.-G. Roßbach \& J. von Maurice (Eds.), Education as a Lifelong Process - The German National Educational Panel Study (NEPS). (Zeitschrift für Erziehungswissenschaft; Special Issue 14) (pp. 5-17). Heidelberg: VS Verlag für Sozialwissenschaften.

Brilli Y,. Del Boca D., Pronzato C. (2016) Does child care availability play a role in maternal employment and children's development? Evidence from Italy. Review of Economics of the Household,14 (1), 83-102.

Cornwell C., Mustard D. (2013) Non-cognitive Skills and the Gender Disparities in Test Scores and Teacher Assessments: Evidence from Primary School. The Journal of Human Resources 48: 236-264.

Contini D. \& Grand E. (2015). On Estimating Achievement Dynamic Models from Repeated Cross-Sections. Sociological Methods and Research, doi: 10.1177/0049124115613773.

Del Boca, D., Flinn, C. \& Wiswall, M. (2014). Household Choices and Child Development. Review of Economic Studies 81 (1), 137-185.

Department for Education and Skills (2007). Gender and education: the evidence on pupils in England, http://webarchive.nationalarchives.gov.uk/20090108131525/http:/dcsf.gov.uk/research/data/uploadfiles /rtp01-07.pdf

De San Román, A. G, \& de La Rica Goiricelaya, S. (2012). Gender gaps in PISA test scores: the impact of social norms and the mother's transmission of role attitudes. IZA Discussion Paper 6338.'

De Simone, G. (2013). Gender unto primary the things which are primary's: Inherited and fresh learning divides in Italian lower secondary education. Economics of Education Review, 35(C), 12-23.

European Commission 2015. Science is a girls' thing, Newsletter Nov. 2015 http://science-girlthing.eu/newsletters/november-2015.html

European Commission 2006, Women in Science and Technology- the Business Perspective, Luxembourg: Office for Official Publication of the European Communities

European Commission 2012, Enhancing excellence, gender equality and efficiency in research and innovation, Luxembourg: Office for Official Publication of the European Communities

Fryer, Roland G., and Steven D. Levitt. 2010. "An Empirical Analysis of the Gender Gap in Mathematics." American Economic Journal: Applied Economics, 2(2): 210-40.

Good, J. J., Woodzicka, J. A., \& Wingfield, L. C. (2010). The effects of gender stereotypic and counterstereotypic textbook images on science performance. Journal of Social Psychology, 150 (2), 132147. 
Guiso L., Monte F., Sapienza P., \& Zingales L. (2008). Culture, gender, and math. Science, 320 (5880), $1164-1165$.

Heckman, J.J., Mosso, S. (2014). The Economics of Human Development and Social Mobility. Annual Review of Economics 6, 689-733.

Heckman, J. J. \& T. Kautz (2012). Hard evidence on soft skills. Labour Economics, 19, 451-464.

Heckman, J. J. \& T. Kautz (2014). Fostering and measuring skills interventions that improve character and cognition. In J. J. Heckman, J. E. Humphries, and T. Kautz (Eds.), The GED Myth: Education, Achievement Tests, and the Role of Character in American Life, Chapter 9. Chicago, IL: University of Chicago Press.

Jacobs, J. E. (1991). Influence of gender stereotypes on parent and child mathematics attitudes. Journal of Educational Psychology, 83 (4), 518-527.

Jacobs, J. E., Lanza S., Osgood D.W., Eccles J.S., Wigfield A. (2002), Changes in children's selfcompetence and values: Gender and domain differences across grades 1 through 12, Child Development, Vol73, pp509-527.

Jacobs, J. E., \& Bleeker, M. M. (2004). Girls' and boys' developing interests in math and science: do parents matter? New Directions for Child and Adolescent Development, 106, 5-21.

Jacobs, J. E., \& Eccles, J. S. (1992). The impact of mothers' gender-role stereotypic beliefs on mothers' and children`s ability perceptions. Journal of personality and Social Psychology, 63(6), 932-944.

Koenker, R., \& Basset G. (1978) Regression Quantiles, Econometrica, Vol 46 (1), pp. 33-50.

Legewie, J., DiPrete, T. A. (2012). School Context and the Gender Gap in Educational Achievement, American Sociological Review 77 (3): 463-85.

Lubienski, S., Robinson, J., Crane, C., Ganley, C. (2013) Girls' and Boys' Mathematics Achievement, Affect, and Experiences: Findings from ECLS-K. Journal for Research in Mathematics Education, 44, 634645.

Mullis, I.V.S., Martin, M.O., Foy, P., \& Arora, A. (2012). TIMSS 2011. International results in mathematics. Chestnut Hill, MA: TIMSS \& PIRLS International Study Center, Boston College.

National Academy of Science (2007) Beyond Bias and Barriers: Fulfilling the Potential of Women in Academic Science and Engineering (2007)

OECD (2013), PISA 2012 Assessment and Analytical Framework: Mathematics, Reading, Science, Problem Solving and Financial Literacy, OECD Publishing. http://dx.doi.org/10.1787/9789264190511-en

OECD. (2015). The ABC of Gender Equality in Education: Aptitude, Behavior, Confidence. PISA Paris: OECD.

Penner, A.M., Parer M., (2008) Gender differences in mathematics achievement: Exploring the early grades and the extremes Social Science Research 37 (1), 239-253

Robinson Joseph P. and Lubiensky Sarah T. (2011) The Development of Gender Achievement Gaps in Mathematics and Reading During Elementary and Middle School Examining Direct Cognitive Assessments and Teacher Ratings. American Educational Resources Journal. 48, 2268-302

Robinson-Cimpian JP, Lubienski ST, Ganley CM, Copur-Gencturk Y (2014) Teachers' perceptions of students' mathematics proficiency may exacerbate early gender gaps in achievement. Development Psychology 50(4):1262-81. doi: 10.1037/a0035073.

Twenge, J. M., \& W. K. Campbell. (2001). Age and birth cohort differences in self-esteem: a cross-temporal meta-analysis. Personality and Social Psychology Review, 5(4), 735-748. 
Verbeek, M. \& Vella, F. (2005) Estimating dynamic models from repeated cross-sections, Journal of Econometrics, 127, 83-102

Zohar, A., \& Sela, D. (2003). Her physics, his physics: gender issues in Israeli advanced placement physics classes." International Journal of Science Education, 25(2), 245-268. 


\section{Appendix}

Table A1: Descriptive statistics (estimation samples from Invalsi 2013)

\begin{tabular}{|c|c|c|c|c|c|}
\hline Gender & Year 2 & Year 5 & Year 6 & Year 8 & Year 10 \\
\hline Male & 48.39 & 49.97 & 50.29 & 50.40 & 50.80 \\
\hline Female & 51.61 & 50.03 & 49.71 & 49.60 & 48.79 \\
\hline Missing & & & & & 0.41 \\
\hline \multicolumn{6}{|l|}{ ESCS index } \\
\hline Mean & n.a. & 0.0664 & 0.1033 & n.a. & -0.0013 \\
\hline Standard deviation & & 1.0194 & 0.9842 & & 0.9795 \\
\hline \multicolumn{6}{|l|}{ Region of residence } \\
\hline North-West & 16.67 & 16.26 & 19.29 & 18.47 & 18.78 \\
\hline North-East & 19.90 & 19.83 & 21.04 & 20.41 & 20.75 \\
\hline Centre & 18.05 & 17.32 & 18.06 & 19.01 & 17.62 \\
\hline South & 25.60 & 26.19 & 23.61 & 23.02 & 24.52 \\
\hline Islands & 19.78 & 20.39 & 18.00 & 19.08 & 18.33 \\
\hline \multicolumn{6}{|l|}{ Maternal education } \\
\hline Degree & 16.49 & 14.21 & 13.23 & 12.70 & 18.95 \\
\hline High school & 34.01 & 33.73 & 32.21 & 29.64 & 35.20 \\
\hline Middle school & 29.49 & 32.76 & 36.86 & 35.27 & 37.56 \\
\hline Missing & 20.01 & 19.29 & 17.70 & 22.39 & 8.29 \\
\hline \multicolumn{6}{|l|}{ Paternal education } \\
\hline Degree & 12.27 & 11.49 & 11.17 & 10.90 & 17.56 \\
\hline High school & 29.76 & 28.66 & 27.05 & 25.67 & 31.81 \\
\hline Middle school & 36.54 & 39.49 & 42.80 & 39.94 & 39.79 \\
\hline Missing & 21.43 & 20.36 & 18.98 & 23.49 & 10.84 \\
\hline Number of siblings & n.a. & & & n.a. & \\
\hline 0 & & 15.19 & 15.40 & & 14.74 \\
\hline 1 & & 54.50 & 56.24 & & 55.32 \\
\hline 2 & & 19.65 & 20.68 & & 22.06 \\
\hline 3 & & 4.61 & 4.70 & & 4.93 \\
\hline$>=4$ & & 2.24 & 2.56 & & 2.40 \\
\hline Missing & & 3.81 & 0.42 & & 0.56 \\
\hline Type of high school attended & n.a. & n.a. & n.a & n.a. & \\
\hline Lyceum & & & & & 44.57 \\
\hline Technical HS & & & & & 21.97 \\
\hline Vocational HS & & & & & 33.46 \\
\hline
\end{tabular}


Table A2 - Effect of other independent variables on achievements in Mathematics (OLS and School FE)

\begin{tabular}{|c|c|c|c|c|c|c|c|c|c|c|}
\hline & \multirow[b]{2}{*}{ Year 2} & \multicolumn{4}{|c|}{ OLS } & \multicolumn{5}{|c|}{ School Fixed effects } \\
\hline & & Year 5 & Year 6 & Year 8 & Year10 & Year 2 & Year 5 & Year 6 & Year 8 & Year10 \\
\hline Escs index & n.a & $\begin{array}{l}0.130 \\
(0.011)^{* * *}\end{array}$ & $\begin{array}{l}0.179 \\
(0.011)^{* * *}\end{array}$ & n.a & $\begin{array}{l}0.156 \\
(0.009)^{* * *}\end{array}$ & n.a & $\begin{array}{l}0.123 \\
(0.011)^{* * *}\end{array}$ & $\begin{array}{l}0.160 \\
(0.011)^{* * *}\end{array}$ & n.a & $\begin{array}{l}0.036 \\
(0.007)^{* * *}\end{array}$ \\
\hline Escs*Fem & n.a. & $\begin{array}{l}0.005 \\
(0.013)\end{array}$ & $\begin{array}{l}-0.012 \\
(0.012)\end{array}$ & n.a. & $\begin{array}{l}-0.031 \\
(0.010)^{* * *}\end{array}$ & n.a. & $\begin{array}{l}0.000 \\
(0.012)\end{array}$ & $\begin{array}{l}-0.021 \\
(0.012)^{*}\end{array}$ & n.a. & $\begin{array}{l}-0.010 \\
(0.008)\end{array}$ \\
\hline \multicolumn{11}{|l|}{$\begin{array}{l}\text { Region of } \\
\text { residence } \\
\text { (ref NW) }\end{array}$} \\
\hline North-East & $\begin{array}{l}0.028 \\
(0.019)\end{array}$ & $\begin{array}{l}-0.032 \\
(0.019)^{*}\end{array}$ & $\begin{array}{l}-0.054 \\
(0.19)^{* * *}\end{array}$ & $\begin{array}{l}0.086 \\
(0.019)^{* * *}\end{array}$ & $\begin{array}{l}0.006 \\
(0.015)\end{array}$ & - & - & - & - & - \\
\hline Centre & $\begin{array}{l}-0.047 \\
(0.026)\end{array}$ & $\begin{array}{l}-0.138 \\
(0.020)^{* * *}\end{array}$ & $\begin{array}{l}-0.254 \\
(0.019)^{* * *}\end{array}$ & $\begin{array}{l}-0.064 \\
(0.019)^{* * * *}\end{array}$ & $\begin{array}{l}-0.372 \\
(0.015)^{* * *}\end{array}$ & - & - & - & - & - \\
\hline South & $\begin{array}{l}-0.219 \\
(0.018)^{* * *}\end{array}$ & $\begin{array}{l}-0.251 \\
(0.019)^{* * *}\end{array}$ & $\begin{array}{l}-0.438 \\
(0.017)^{* * *}\end{array}$ & $\begin{array}{l}-0.215 \\
(0.018)^{* * *}\end{array}$ & $\begin{array}{l}-0.629 \\
(0.014)^{* * *}\end{array}$ & - & - & - & - & - \\
\hline Islands & $\begin{array}{l}-0.259 \\
(0.020)^{* * *}\end{array}$ & $\begin{array}{l}-0.382 \\
(0.020)^{* * *}\end{array}$ & $\begin{array}{l}-0.632 \\
(0.019)^{* * *}\end{array}$ & $\begin{array}{l}-0.095 \\
(0.019)^{* * *}\end{array}$ & $\begin{array}{l}-0.769 \\
(0.015)^{* * *}\end{array}$ & - & - & - & - & - \\
\hline \multicolumn{11}{|l|}{$\begin{array}{l}\text { Maternal } \\
\text { education } \\
\text { (ref }\end{array}$} \\
\hline High & -0.145 & -0.129 & -0.028 & -0.216 & -0.026 & -0.143 & -0.119 & -0.032 & -0.160 & 0.002 \\
\hline & $(0.021)^{* * *}$ & $(0.023)^{* * *}$ & $(0.022)$ & $(0.023)^{* * * *}$ & $(0.015)^{*}$ & $(0.020)^{* * *}$ & $(0.022)^{* * *}$ & $(0.022)$ & $(0.021)^{* * *}$ & $(0.012)$ \\
\hline Middle & -0.407 & -0.296 & -0.212 & -0.486 & -0.149 & -0.380 & -0.288 & -0.209 & -0.422 & -0.027 \\
\hline & $(0.023)^{* * *}$ & $(0.028)^{* * *}$ & $(0.026)^{* * *}$ & $(0.024)^{* * *}$ & $(0.018)^{* * *}$ & $(0.022)^{* * *}$ & $(0.026)^{* * *}$ & $(0.026)^{* * *}$ & $(0.022)^{* * *}$ & $(0.014)^{*}$ \\
\hline Missing & $\begin{array}{l}-0.207 \\
(0.035)^{* * *}\end{array}$ & $\begin{array}{l}-0.145 \\
(0.039)^{* * *}\end{array}$ & $\begin{array}{l}-0.177 \\
(0.035)^{* * *}\end{array}$ & $\begin{array}{l}-0.277 \\
(0.035)^{* * *}\end{array}$ & $\begin{array}{l}-0.139 \\
(0.025)^{* * *}\end{array}$ & $\begin{array}{l}-0.285 \\
(0.037)^{* * *}\end{array}$ & $\begin{array}{l}-0.219 \\
(0.041)^{* * *}\end{array}$ & $\begin{array}{l}-0.213 \\
(0.038)^{* * *}\end{array}$ & $\begin{array}{l}-0.317 \\
(0.035)^{* * *}\end{array}$ & $\begin{array}{l}-0.071 \\
(0.020)^{* * *}\end{array}$ \\
\hline $\begin{array}{l}\text { Paternal } \\
\text { education } \\
\text { (ref } \\
\text { University) }\end{array}$ & & & & & & & & & & \\
\hline High & -0.103 & -0.007 & -0.031 & -0.090 & -0.004 & -0.111 & -0.021 & -0.045 & -0.055 & 0.038 \\
\hline & $(0.023)^{* * *}$ & $(0.025)$ & $(0.024)$ & $(0.024)^{* * *}$ & $(0.016)$ & $(0.022)^{* * *}$ & $(0.024)$ & $(0.023)^{* *}$ & $(0.022)$ & $(0.013)^{* * *}$ \\
\hline Middle & -0.305 & -0.141 & -0.152 & -0.334 & -0.118 & -0.329 & -0.171 & -0.183 & -0.282 & 0.005 \\
\hline & $(0.024)^{* * *}$ & $(0.028)^{* * *}$ & $(0.026) * * *$ & $(0.025)^{* * *}$ & $(0.018)^{* * *}$ & $(0.023)^{* * *}$ & $(0.027)^{* * *}$ & $(0.026)^{* * *}$ & $(0.023)^{* * *}$ & $(0.014)$ \\
\hline Missing & $\begin{array}{l}-0.268 \\
0.035\end{array}$ & $\begin{array}{l}-0.097 \\
(0.040)^{* *}\end{array}$ & $\begin{array}{l}-0.115 \\
(0.036)^{* * *}\end{array}$ & $\begin{array}{l}-0.271 \\
(0.035)^{* * *}\end{array}$ & $\begin{array}{l}-0.172 \\
(0.023)^{* * *}\end{array}$ & $\begin{array}{l}-0.347 \\
(0.035)^{* * *}\end{array}$ & $\begin{array}{l}-0.155 \\
(0.040)^{* * *}\end{array}$ & $\begin{array}{l}-0.157 \\
(0.036)^{* * *}\end{array}$ & $\begin{array}{l}-0.299 \\
(0.033)^{* * *}\end{array}$ & $\begin{array}{l}-0.052 \\
(0.019)^{* * *}\end{array}$ \\
\hline $\begin{array}{l}\text { N. siblings } \\
\text { (ref 0) }\end{array}$ & n.a. & & & n.a. & & n.a & & & n.a & \\
\hline 1 & & $\begin{array}{l}-0.002 \\
(0.018)\end{array}$ & $\begin{array}{l}0.020 \\
(0.017)\end{array}$ & & $\begin{array}{l}0.055 \\
(0.014)^{* * *}\end{array}$ & & $\begin{array}{l}-0.006 \\
(0.017)\end{array}$ & $\begin{array}{l}0.012 \\
(0.017)\end{array}$ & & $\begin{array}{l}0.048 \\
(0.012)^{* * *}\end{array}$ \\
\hline 2 & & $\begin{array}{l}-0.059 \\
(0.022)^{* * *}\end{array}$ & $\begin{array}{l}-0.077 \\
(0.020)^{* * *}\end{array}$ & & $\begin{array}{l}0.014 \\
(0.016)\end{array}$ & & $\begin{array}{l}-0.054 \\
(0.021)^{* *}\end{array}$ & $\begin{array}{l}-0.057 \\
(0.020)^{* * *}\end{array}$ & & $\begin{array}{l}0.052 \\
(0.014)^{* * *}\end{array}$ \\
\hline 3 & & $\begin{array}{l}-0.092 \\
(0.033)^{* * *}\end{array}$ & $\begin{array}{l}-0.174 \\
(0.031)^{* * *}\end{array}$ & & $\begin{array}{l}0.019 \\
(0.025)\end{array}$ & & $\begin{array}{l}-0.110 \\
(0.032)^{*}\end{array}$ & $\begin{array}{l}-0.163 \\
(0.031)^{* * *}\end{array}$ & & $\begin{array}{l}0.091 \\
(0.022)^{* * * *}\end{array}$ \\
\hline$>4$ & & $\begin{array}{l}-0.219 \\
(0.045)^{* * *}\end{array}$ & $\begin{array}{l}-0.280 \\
(0.040)^{* * *}\end{array}$ & & $\begin{array}{l}-0.074 \\
(0.033)^{* *}\end{array}$ & & $\begin{array}{l}-0.211 \\
(0.043)^{* * *}\end{array}$ & $\begin{array}{l}-0.234 \\
(0.040)^{* * *}\end{array}$ & & $\begin{array}{l}0.030 \\
(0.030)\end{array}$ \\
\hline $\mathrm{N}$ & 21988 & 21207 & 24074 & 25111 & 33479 & 21998 & 21207 & 24074 & 25111 & 33519 \\
\hline $\mathrm{R}^{2}$ & 0.0756 & 0.1041 & 0.167 & 0.082 & 0.203 & 0.059 & 0.0915 & 0.107 & 0.071 & 0.048 \\
\hline
\end{tabular}

Notes. Std errors are in brackets. * indicates that the underlying coefficient is significant at $10 \%$ level, $* *$ at $5 \%$ and $* * * 1 \%$ 
Table A3 - Effect of other independent variables on achievements in Maths. Dynamic models

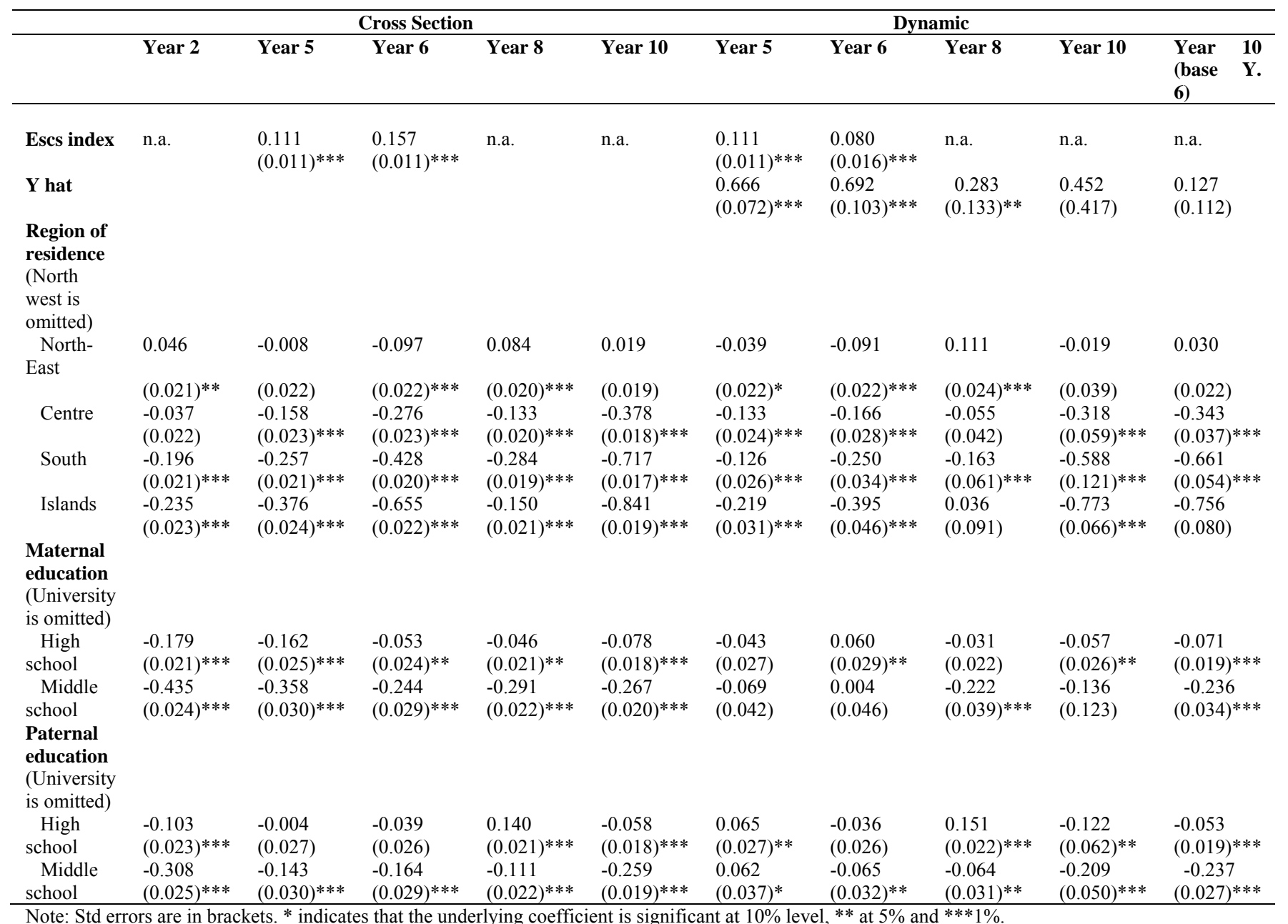


Table A4 - Attitudes towards maths

\begin{tabular}{|c|c|c|c|}
\hline & (\% all sample) & \%Girls & \%Boys \\
\hline What do you think of mathematics? & Year 5 & & \\
\hline I am good at maths & 74.49 & 70.33 & 78.64 \\
\hline Maths is hard & 23.26 & 27.31 & 19.20 \\
\hline I learn maths easily & 63.30 & 59.14 & 67.47 \\
\hline I have fun doing maths & 61.18 & 56.75 & 65.61 \\
\hline I'd like to do more maths a school & 37.16 & 31.68 & 42.65 \\
\hline What do you think of mathematics? & Year 6 & & \\
\hline \multicolumn{4}{|l|}{ I am good at maths } \\
\hline Strongly disagree & 4.10 & 4.90 & 3.36 \\
\hline Disagree & 18.73 & 21.50 & 16.01 \\
\hline Agree & 54.93 & 56.00 & 53.87 \\
\hline Strongly agree & 22.03 & 17.50 & 26.52 \\
\hline Missing & 0.21 & 0.17 & 0.25 \\
\hline \multicolumn{4}{|l|}{ Mathematics is hard } \\
\hline Strongly disagree & 38.11 & 36.51 & 39.69 \\
\hline Disagree & 38.30 & 38.40 & 38.21 \\
\hline Agree & 17.71 & 18.86 & 16.58 \\
\hline Strongly agree & 5.54 & 5.96 & 5.12 \\
\hline Missing & 0.34 & 0.26 & 0.41 \\
\hline \multicolumn{4}{|l|}{ I learn maths easily } \\
\hline Strongly disagree & 7.56 & 8.74 & 6.40 \\
\hline Disagree & 19.89 & 21.97 & 17.84 \\
\hline Agree & 44.70 & 45.61 & 43.81 \\
\hline Strongly agree & 27.50 & 23.39 & 31.56 \\
\hline Missing & 0.35 & 0.30 & 0.39 \\
\hline \multicolumn{4}{|l|}{ I have fun doing maths } \\
\hline Strongly disagree & 20.62 & 22.13 & 19.13 \\
\hline Disagree & 22.87 & 24.46 & 21.30 \\
\hline Agree & 31.95 & 31.76 & 32.13 \\
\hline Strongly agree & 24.29 & 21.43 & 27.11 \\
\hline Missing & 0.27 & 0.22 & 0.33 \\
\hline \multicolumn{4}{|l|}{ I'd like to do more maths at school } \\
\hline Strongly disagree & 37.12 & 39.63 & 34.63 \\
\hline Disagree & 28.82 & 29.55 & 28.10 \\
\hline Agree & 20.68 & 19.72 & 21.63 \\
\hline Strongly agree & 13.18 & 10.92 & 15.42 \\
\hline Missing & 0.20 & 0.18 & 0.22 \\
\hline $\begin{array}{l}\text { I believe that being good at Maths will help me } \\
\text { in life }\end{array}$ & $\begin{array}{r}\text { Year } 10 \\
(\%)\end{array}$ & & \\
\hline Strongly disagree & 6.14 & 5.64 & 6.62 \\
\hline Disagree & 27.4 & 29.43 & 25.59 \\
\hline Agree & 51.49 & 51.98 & 50.98 \\
\hline Strongly agree & 14.33 & 12.35 & 16.21 \\
\hline Missing & 0.60 & 0.60 & 0.60 \\
\hline \multicolumn{4}{|l|}{$\begin{array}{l}\text { I need to understand Maths in order to learn } \\
\text { other subjects at school }\end{array}$} \\
\hline Strongly disagree & 10.68 & 12.28 & 9.16 \\
\hline Disagree & 35.48 & 39.71 & 31.46 \\
\hline Agree & 42.01 & 39.07 & 44.80 \\
\hline Strongly agree & 11.20 & 8.35 & 13.91 \\
\hline Missing & 0.63 & 0.60 & 0.67 \\
\hline \multicolumn{4}{|l|}{$\begin{array}{l}\text { I need to be good at Maths in order to choose } \\
\text { what to do after school }\end{array}$} \\
\hline Strongly disagree & 18.65 & 21.69 & 15.76 \\
\hline Disagree & 34.77 & 38.19 & 31.56 \\
\hline Agree & 33.41 & 29.70 & 36.96 \\
\hline Strongly agree & 12.49 & 9.80 & 14.97 \\
\hline Missing & 0.69 & 0.62 & 0.75 \\
\hline \multicolumn{4}{|l|}{$\begin{array}{l}\text { I need to be good at Maths in order to get a } \\
\text { good job }\end{array}$} \\
\hline Strongly disagree & 18.78 & 21.85 & 15.85 \\
\hline Disagree & 31.87 & 34.50 & 29.42 \\
\hline Agree & 32.93 & 30.61 & 35.17 \\
\hline Strongly agree & 15.71 & 12.37 & 18.80 \\
\hline Missing & 0.72 & 0.68 & 0.76 \\
\hline
\end{tabular}

